if they were). If, as seems likely, a comprehensive test-ban agreement would be the best way of ensuring the continuation of the NPT, the two years left before the 1995 conference are hardly time enough. But would it not be a great misfortune if the NPT fell apart for lack of the time in which to make its continuation likely? That is one good reason why the US Congress has done the world a public service by advertising the importance of the test-ban issue.

Unfortunately, there is still more to be done before 1995. The past few years have shown all too well that the tendency towards nuclear proliferation has not melted away. Who can be sure, for example, that neither Iran (a signatory of the NPT since the Shah's time) nor Pakistan (not a signatory) is following along the road pioneered by Iraq? As things are now, even compliance by India (a conspicuous non-signatory) would not necessarily secure that of Pakistan, which may (like Iran) believe it has a duty towards the Muslim Middle East, already polarized by Israel's cryptonuclear status. And what is to be made of the ex-Soviet republics other than Russia? The Russian government claims to be the inheritor of the Soviet Union's international obligations, but is it in a position to assure its partners of the compliance of its lesser neighbours, Khazakstan and the Ukraine, for example? It would be a great surprise if it could speak for even the physical integrity of nuclear weapons and unprocessed materials.

That is why there is no time to waste in preparing for the NPT conference in 1995, the year after next, which, by the standards of diplomacy, may be likened to the day after tomorrow. There is endless persuasion of recalcitrant nuclear powers to be done, not to mention technical work on the treaty itself and on the safeguards regime required for a future now likely to be very different from what seemed possible a few years ago. (The case of Iraq has shown that the safeguards regime should ideally concentrate on the most suspicious countries, however inegalitarian that may seem.) It is a great waste of scarce resources that the inspection agency, the International Atomic Energy Agency in Vienna, should deal on an equal footing with, say, Sweden and Khazakhstan. Proliferators would cry "discrimination" if the present rules were changed, but that is a revealing cry.

There remain over-arching questions such as whether non-compliance with an amended NPT would justify expulsion from the United Nations. That question, prompted by recent moves towards enforcement in the UN Security Council, will surely be answered "No" unless there is a test-ban. Meanwhile, the most urgent need is for the non-signatory nuclear powers, France and China, to be brought into the fold. It is ridiculous that they stand aside from a treaty they say they abide by in all except name. It helps a little that France has recently been making eyes at Britain on co-ordination of nuclear policy. Britain, with hardly any other international influence left, should seize the chance for the common good.

\section{Megaprojects galore}

\section{Europe seems keen on construction projects with ben- efits for the environment: will environmentalists agree?}

EvEN if the European enterprise is temporarily under a cloud of scepticism, even disbelief, Europe's physical monuments to its hopes of closer union appear to be multiplying fast. Last week, the waterway joining the Danube with the Rhine was opened for traffic, more than a millennium after people in Europe first started talking about some such scheme. At the same time, the Swiss population has voted in favour of an ingenious, if costly, way of keeping heavy traffic off rural Alpine roads; Switzerland will now probably sign a treaty with the European Communities (EC) giving it exemption from Europe's highway standards in return for a means of transporting trucks beneath the Alps on flatcars. Both tunnels, beneath the Gotthard and the Lötschberg, should be in place early next decade. The Swiss tunnels, the longer of which is 50 kilometres long, are comparable in scale with the tunnel beneath the English Channel (otherwise La Manche), which should be operating within a year.

Interestingly, all three schemes have been partly inspired by environmental considerations, and in particular by the wish to transfer the transport of goods from overstressed road networks. The link between the Rhine and Danube waterway systems will have overt and substantial economic benefits as well. All three will also allow charges for the costs of transport to be levied directly on the beneficiaries, which is a sensible longstanding goal. The projects are therefore striking illustrations of how improvements of the environment can be brought about by civil engineers, whose construction schemes are nevertheless opposed as almost as a matter of routine by those professing care for the quality of the environment. It is a question of some importance whether Europe's environmental organizations, coloured various shades of green, can be persuaded to give Europe's future megaprojects the welcome they deserve.

There are a lot of them ahead. The EC, urged on by the SNCF (the French railway) has been dreaming of a network of fast railways throughout its own region and penetrating far into the east. These projects will inevitably require land now occupied by houses and other unrelated structures. The evolution of this European railway network will be a fierce test of the green lobby's willingness to put the greater good ahead of narrow sectional interests. It has not, so far, done well; in the case of the British proposal to build a high-speed railway link between the landfall of the Channel tunnel (called Eurotunnel), environmental interests in South-East England have so far forced revisions of the preferred route which are so costly that, in present economic circumstances, it is unaffordable. It is to be hoped that Europe as a whole will be more deliberately level-headed. 